\title{
Understanding the Consumers' Personal Characteristics as the Starting Point for Targeted Marketing
}

\author{
TINA VUKASOVIĆ \\ University of Primorska, Slovenia \\ tina.vukasovic@upr.si
}

\begin{abstract}
Market segmentation and choosing target markets allow companies to distinguish and position their offer and to plan their marketing activities in a manner allowing them to come as close to consumers as possible. A company doing business in a large market soon realises that it cannot supply to all consumers in this market. There can be too many of them, they can differ with regard to their requirements, can be scattered across the market, or their purchasing demands are substantially different. The main objective of the market research, whose main results are presented in the article, was to research consumers' lifestyle, personal values and media habits. The quantitative research method was chosen and the technique of online surveying. The research results will be used as a basis for market segmentation and for creating effective marketing messages and choosing appropriate marketing communication tools in the analysed market.
\end{abstract}

Key words: lifestyle, values, consumer, market segmentation, marketing strategy, media, marketing communication, Croatia

\section{Introduction}

The core of the contemporary marketing strategy of the 21st century is comprised of segmentation, choosing target markets, and positioning, which is also called target marketing (Vukasović and Jagodič 2017). Companies are learning that mass marketing and marketing of diverse products is becoming increasingly difficult. Mass markets are getting smaller and are disintegrating into hundreds of small markets which are characterised by consumers searching for various products through various sales channels and paying attention to various communication channels. Companies are increasingly accepting target marketing. The latter presents the first step of strategic thinking in contemporary companies. Utilising a deliberate approach to target marketing, companies create the right relationships 
with the right consumers. In order for target marketing to be successful, the market has to be researched and the key markets determined, i.e. market segmentation followed by brand, products and services positioning (Vukasović 2018).

Segmentation can be defined as breaking down the market into various groups of consumers. Here, the target group can be found and reached using the right marketing mix (Damjan and Možina 1995). The main element of such a strategy is the focus on one or more narrower segments instead of on the whole market, as companies have limited resources and cannot meet all of the consumers' requirements. A segmented approach to the market brings a significant general advantage to the organisation, i.e. better familiarity with consumers in an individual segment, which means it is able to better adapt to their needs and requirements (Vukasović 2018).

Companies need a lot of data on consumers, their wishes, requirements, and characteristics in order to adapt their marketing activities and be successful in the market. Company management usually does not have direct contact with consumers, does not know them, and consequently does not have all the required data. These data can be obtained with market research; however, they also need to be processed prior to use. One of the methods used for this purpose is market segmentation. The results of such processing are appropriate for creating a general picture on the situation in the market and product positioning, as well as for strategic decisions on the development of new products or groups of products. Due to the growing competition in the market and consumers with increasingly complex demands, the bases for market segmentation are becoming more and more complex and segmentation more and more difficult. For this reason, researchers involved with market segmentation began using statistical methods of classification into groups (Solomon, Bamossy, and Askegaard 1999; Kotler 1998; Vukasović 2018).

The main advantages of market segmentation are (McDonald and Dunbar 1995):

- Recognising differences between consumers represents the key to successful marketing, as it enables a more optimal meeting of consumers' needs and desires with the products offered by the company;

- Market segmentation leads to a concentration of company resources in markets where the company's competitive advantage is the most evident and revenue the highest;

- Market segmentation can be used as a way of achieving com- 
petitive advantage by analysing the market differently than the competition (the company chooses its own criteria);

- Market segmentation allows the company to more quickly and effectively implement marketing activities in specific market segments as a specialist and ensures the achieving of competitive advantages of its products through a better understanding of the consumers' needs and desires.

So, why is market segmentation so useful in marketing? Market segmentation is useful in all elements of the marketing mix. It is useful in promotional activities, as advertising, which is supported with market segmentation, plays an important role in product positioning. When it comes to distribution, buyers differ with regard to where they wish to buy. Income segmentation determines the prices of the products with regard to who is buying them. Who the product is intended for also has to be kept in focus when designing the product (Mumel 1999).

\section{Literature Review}

\section{MARKET SEGMENTATION AND BASES FOR CONSUMER MARKET SEGMENTATION}

Segmentation confers to a part of a whole market that requires identifying customers' product needs, grouping them with similarities (Bainess, Fill, and Page 2010; Hawkins, Mothersbaugh, and Mookerjee 2010; Kegan and Bhargava 2010). Segmentation requires narrowing down the macro market into common subsets (Peter and Olson 2013). Geographic, demographic and psychographic phenomena are the bases of segmentation (Kotler et al. 2013). Also, markets must have boundaries (Kamakura and Russell 1989; Natter et al. 2008) to be highly impacted and well defined (Davies and Brooks 1989) having product preference (Dibb and Simkin 1991; Hassan and Craft 2012; Islam 2020).

Targeting means assessing lucrative parts of the markets (Kotler et al. 2013) being distinct, accessible, measurable and profitable uncovered by competitors (Bainess, Fill, and Page 2010). Targeting involves looking for the right segments to offer products, undertaking standardized, concentrated and differentiated offers (Kegan and Bhargava 2010). Besides, targeting indicates developing measures of attractiveness and finalizing the target markets (Kotler et al. 2013). This also needs to be specific, organized, cost-efficient and effective (Dibb and Simkin 1991; Islam 2020).

Depending on the crucial factors, marketers must decide whether 
to undertake broad targeting through mass marketing and differentiated marketing whereas narrow targeting needs niche marketing (Kotler and Armstrong 2016). Additionally, Porter (1985) has mentioned five factors to be considered for targeting suitable segments that include a rivalry, new entrants, substitutes, bargaining power of buyers and suppliers (Islam 2020).

Positioning implies marketer's decision and activities designed to focus and uphold a certain concept in customers' mind (Kegan and Bhargava 2010; Pride and Ferrell 2010). Specifically, positioning strategies include, designing superior customer value in line with quality and price (Kotler and Armstrong 2016; Islam 2020). Positioning, of course, represents a unique feature of a product, shaping the consumer preference, that results in brand loyalty (Fuchs and Diamantopoulos 2010) with a focus of customers' needs, expectations and priorities (Ernst, Hoyer, and Rübsaamen 2010; Fuchs and Diamantopoulos 2010). Positioning highly relies on assessing the needs of targeted segments (Johnson 1987) characterized by price sensitivity (DeSarbo, Ramaswamy, and Cohen 1995). It also represents the 'sharp end' for marketers compared with the closest competitors (Ries and Trout 1981) and a variable parameter taken as granted in customers' view (Dibb and Simkin 1991). However, a viable threat takes place when competitors replicate positioning variables (Moe and Fader 2001; Islam 2020).

The variables which describe market segments are chosen from the group of variables which represent the basis for segmentation (geographic, demographic, etc.), while consumer variables can also be used. The description and formation of segments means that each segment is described with all available and interesting variables (Vukasović 2018).

Groups of variables (Vukasović 2020):

- Descriptive variables: demographic, socioeconomic, psychographic, occasion of use;

- Behavioural variables: benefits sought, desired usage, purchasing patterns and loyalty, participation in the decision-making and dissemination process, brand attitude, sensitivity to marketing mix elements.

Market segmentation using descriptive variables means that consumers are first classified into segments with regard to their characteristics (age, gender, lifestyle, income, etc.) and we then check whether they differ in terms of behavioural variables. Descriptive variables are more easily accessible and individual groups have al- 
ready been formed, which means that it is easier to assess the size of the segments. In segmentation according to behavioural variables, consumers are first classified with regard to behavioural characteristics and the segments are later described with descriptive variables. This second procedure is believed to be better, as market segmentation is prepared on the basis of consumers' requirements and the so-obtained segments present a better basis for the preparation of the marketing mix (Žiberna 2002; Vukasović 2018).

Despite the predominantly similar criteria for market segmentation, another author needs to be mentioned who proposes slightly different criteria for market segmentation. According to Wind, the following variables are the most frequently used basis for market segmentation (Damjan and Možina 1995):

- For general understanding of a market: benefits sought, product purchase and usage patterns, consumers' needs, brand loyalty or a hybrid of the above variables.

- For positioning: product usage, product preference, benefits sought or a hybrid of the variables above.

- For new product introduction: response to new products (intention to buy, preference over current brand, etc.), benefits sought.

- For pricing decisions: price sensitivity, deal proneness, price sensitivity by purchase/usage patterns.

- For advertising decisions: benefits sought, media usage, psychographic or lifestyle, a hybrid of the variables above and purchase/usage patterns.

- For distribution decisions: store loyalty and patronage, benefits sought in store selection.

The above-mentioned variables are rather specific and situationbound. They emphasise the consumers' responses or their responsiveness to marketing stimuli.

When preparing market segmentation, we include various variables which determine the characteristics of individuals who we then combine into groups with regard to common characteristics. These represent the target groups of a company's marketing strategy. There are countless combinations of including variables (from demographic to more complex ones which describe the consumer's behaviour). However, market segmentation does not suffice for a good marketing strategy. We need to develop products and services which can be positioned in the chosen segments. Market segmentation and product positioning have to be developed simultaneously (Vukasović 2018). 
Market segmentation can be successful and useful for preparing the marketing strategy if the following criteria are met (Solomon, Bamossy, and Askegaard 1999):

- Consumers within the segment are similar to one another in terms of product needs, and these needs are different from consumers in other segments;

- Important differences among segments can be identified;

- The segment is large enough to be profitable;

- Consumers in the segment can be reached by an appropriate marketing mix;

- The consumers in the segment will respond in the desired way to the marketing mix designed for them.

Throughout the years of developing different theories, marketing experts have developed every possible configuration of segmentation and combination of variables for achieving the best possible and most appropriate profile of the main groups of consumers. However, changes in consumers' lifestyles and other characteristics of the population bring new marketing opportunities. In order for segmentation to be successful, establishing connections between consumers who have the same of similar lifestyle has also proven to be effective, as these data are more relevant than the basic demographic and geographic data and actually express similarity (Vukasović 2018).

One of the most famous and popular market segmentation systems on the basis of values and lifestyle was developed at an American research institute (vals - Values and Lifestyles). The system is based on Maslow's hierarchy of needs and the theory by the sociologist David Riesman who distinguishes between people, who value personal expression and individual taste, and people, who tend to be swayed by the behaviour and reactions of others (Solomon, Bamossy, and Askegaard 1999).

Market segmentation discovers opportunities which represent the market segment for individual companies. The company needs to assess various segments and decide on how many and which segments to focus.

\section{Materials and Methods}

METHODOLOGY, DATA COLLECTION AND SAMPLE

The quantitative research method was chosen and the technique of online surveying. Surveying was performed using an online survey. The link to the survey was sent to the respondents' email addresses. The questionnaire was substantially the same structure as 
TABLE 1 Respondents' Characteristics

\begin{tabular}{llrr}
\hline Category & Group & $\mathrm{f}$ & $\%$ \\
\hline Respondents' age & Up to 24 years old & 27 & 12 \\
& 25 to 34 years old & 69 & 32 \\
& 35 to 44 years old & 73 & 33 \\
& Over 45 years old & 50 & 23 \\
\cline { 2 - 4 } & Total & 219 & 100.0 \\
\hline Respondents' status & Secondary school student & 2 & 1 \\
& Student & 12 & 5 \\
& Employed or self-employed & 170 & 78 \\
& Unemployed & 21 & 10 \\
& Retired & 2 & 1 \\
& Other & 12 & 5 \\
\cline { 2 - 4 } & Total & 219 & 100.0 \\
\hline Field of employment & Economic sector & 99 & 58 \\
& Public sector & 71 & 42 \\
\cline { 2 - 4 } & Total & 170 & 100.0 \\
\hline
\end{tabular}

in Vukasović (2018) but conducted on different market and different population.

262 respondents participated in the study. 219 respondents provided their gender. Of those there were 77 male respondents $(35 \%$ of respondents) and 142 female respondents (65\% of respondents).

So as to facilitate the assessment of respondents according to age, they were classified into four age groups. Table 1 presents the four age groups of respondents. The highest share of the 219 respondents belong to the 35 to 44 age group, i.e. 73 respondents or $33 \%$ of all respondents. This is followed by the group of respondents belong to the 25 to 34 age group, i.e., 69 respondents or $32 \%$ of all respondents.

Before the implementation of the study, the following hypotheses were formulated:

$\mathrm{H} 1$ The most important values determined by the respondents are being fair and honest.

н2 The most emphasised values determined by the respondents are honesty, reliability and respect.

н3 The most popular topics that respondents follow on a daily basis are global news, information on work, studying, and leisure time, economy and finance and news from country.

$\mathrm{H} 4$ The most frequently used media through which respondents obtain the majority of information are $\mathrm{TV}$ channels, web portals and social networks. 


\section{Results and Discussion}

Analysing the respondents' status, table 1 shows that the majority of the respondents ( 170 or $78 \%$ ) provided employed or self-employed as their current status. This is followed by the unemployed (21 respondents or $10 \%$ ), and students (12 respondents or $5 \%$ ).

170 respondents provided their answers on the field of employment. The majority, i.e. 99 respondents or $58 \%$, work in the economic sector, while 71 respondents or $42 \%$ work in the public sector (table 1).

The research focused on consumer's lifestyle and personal characteristics, to the attitude towards different personal values or things which consumers see as the guiding principles which give meaning to their lives. The respondents answered our question using a fivepoint Likert scale, with 1 meaning that a statement does not apply to the respondent at all and 5 that a statement fully applies to the respondent. The respondents could freely choose a number from 1 to 5 .

Table 2 shows the respondents' attitude towards different personal values or things which the respondents see as the guiding principles which give meaning to their lives. 227 respondents answered the question. The most important values determined by the respondents were safety of loved ones. This statement was chosen by 175 (77\%) respondents. The respondents also being fair, honest very important. This statement was chosen by $162(71 \%)$ respondents. According to the respondents, the least important characteristic is the traditional division of roles into male and female roles. These results allow us to reject hypothesis 1 (H1) that 'The most important values determined by the respondents is being fair and honest.'

The next set of statements refers to the respondents' personal characteristics. The respondents had to indicate their level of agreement with an individual statement. A five-point Likert scale was used, with 1 meaning that they completely disagree with a statement and 5 that they fully agree with it.

Table 3 presents the respondents' personal characteristics. This question focused on the respondents' personal characteristics. 224 respondents answered the question. 108 respondents (48\%) find cooperation, help, and encouraging others to be very important. 99 (44\%) respondents value different opinions, are willing to accept additional information and knowledge, and upgrade existing knowledge through research. 95 (42\%) respondents are organised, responsible, and persistent. 
TABle 2 The Respondents' Attitude towards Different Personal Values or Things which the Respondents See as the Guiding Principles Which Give Meaning to Their Lives

\begin{tabular}{lrrr}
\hline Values & $f$ & $\%$ & $\bar{x}$ \\
\hline Safety of loved ones & 175 & 77 & 4.7 \\
Being fair, honest & 162 & 71 & 4.7 \\
Doing things I love & 151 & 67 & 4.6 \\
Helping others & 130 & 57 & 4.5 \\
Equal opportunities for all & 111 & 49 & 4.3 \\
Achieving a higher standard & 96 & 42 & 4.3 \\
Exciting experience & 60 & 26 & 3.9 \\
Having fun & 56 & 25 & 3.9 \\
Material goods, having a lot of money & 54 & 24 & 3.9 \\
Being different from other people & 49 & 22 & 3.7 \\
Living according to principles dictated by religion & 48 & 21 & 3.2 \\
Maintaining tradition & 23 & 10 & 3.2 \\
Traditional division of roles into male and female roles & 12 & 5 & 2.1 \\
\hline
\end{tabular}

TABLE 3 Respondents' Personal Characteristics

\begin{tabular}{lrrr}
\hline Characteristics & $f$ & $\%$ & $\bar{x}$ \\
\hline I am a cooperative person, I like to help, and encourage others. & 108 & 48 & 4.4 \\
I am inquisitive, of a vivid imagination, I appreciate different & 99 & 44 & 4.3 \\
opinions and ideas. & & & \\
I am responsible, organised, persistent. & 95 & 42 & 4.3 \\
I am thorough in my work. & 89 & 40 & 4.3 \\
I am considerate and kind to almost everyone. & 87 & 39 & 4.2 \\
I appreciate artistic and aesthetic experiences. & 74 & 33 & 4.0 \\
I am original and often come up with new ideas. & 70 & 31 & 4.1 \\
I am effective in what I do. & 64 & 29 & 4.1 \\
I am talkative. & 53 & 24 & 3.7 \\
I remain calm in stressful situations. & 52 & 23 & 3.9 \\
I forgive people easily. & 37 & 17 & 3.5 \\
I am often worried. & 18 & 8 & 3.1 \\
I quickly get nervous. & 7 & 3 & 2.5 \\
\hline
\end{tabular}

The study further focused on the values with which the respondents associate their personality. The respondents could choose a maximum of five values.

Table 4 shows the values which the respondents associate with themselves. The six most frequently chosen values are shown. We were interested in the relation between the chosen value and the respondents' gender. Honesty is the most emphasised value. 45 (34\%) 
TABLE 4 Values with which the Respondents Associate Their Personality

\begin{tabular}{|c|c|c|c|c|c|c|}
\hline \multirow[t]{2}{*}{ Values } & \multicolumn{2}{|c|}{ Male } & \multicolumn{2}{|c|}{ Female } & \multicolumn{2}{|c|}{ Total } \\
\hline & $\bar{f}$ & $\%$ & $f$ & $\%$ & $f$ & $\%$ \\
\hline Honesty & 45 & 33.83 & 88 & 66.17 & 133 & 100 \\
\hline Reliability & 34 & 28.57 & 85 & 71.43 & 119 & 100 \\
\hline Respect & 33 & 29.46 & 79 & 70.54 & 112 & 100 \\
\hline Flexibility & 33 & 35.87 & 59 & 64.13 & 92 & 100 \\
\hline Ambitiousness & 32 & 37.21 & 54 & 62.79 & 86 & 100 \\
\hline Originality & 6 & 28.57 & 15 & 71.43 & 21 & 100 \\
\hline Total & 183 & 32.50 & 380 & 67.50 & 563 & 100 \\
\hline
\end{tabular}

men and 88 (66\%) women chose this value. The second most frequently chosen value is reliability, which was chosen by $34(29 \%)$ men and $85(71 \%)$ women. 33 (29\%) men and 79 (71\%) women chose the value of respect. In light of the data obtained with our study, we can say that the percentage of positive personal values is higher among women than it is among men. The lowest number of respondents, i.e. $6(28 \%)$ men and $15(71 \%)$ women, chose the value of originality as the least important. These results allow us to confirm hypothesis 2 (н2) that 'The most emphasised values determined by the respondents are honesty, reliability and respect.'

The next set of questions refers to the following and use of media in respondents' everyday lives.

We established the most popular topics that respondents follow on a daily basis:

- Information on work, studying, and leisure time (175; 78\%);

- Global news (155; 70\%);

- News from country (154;69\%);

- Economy and finance $(151 ; 68 \%)$;

- Local information (147;66\%);

- Science and technology (141;63\%).

The highest share pertains to topics associated with information on work, studying, and leisure time. These results allow us to confirm hypothesis 3 (н3) that 'The most popular topics that respondents follow on a daily basis are global news, information on work, studying, and leisure time, economy and finance and news from country.'

It was further established that web portals, Tv channels, search engines, and social networks are the most frequently used media through which respondents obtain the majority of information with regard to individual fields (table 5). These results allow us to con- 
TABLE 5 The Most Frequently Used Media as a Source of Information for Individual Fields

\begin{tabular}{lrrrrrrr}
\hline Fields & $(1)$ & $(2)$ & $(3)$ & $(4)$ & $(5)$ & $(6)$ & $(7)$ \\
\hline News from country & 55 & 7 & 4 & 105 & 23 & 25 & 218 \\
Local information & 21 & 24 & 14 & 96 & 21 & 42 & 218 \\
Global events & 51 & 5 & 6 & 115 & 23 & 18 & 218 \\
Information on work, studying, & 7 & 1 & 5 & 123 & 64 & 18 & 218 \\
and leisure time & & & & & & & \\
Sports & 67 & 6 & 5 & 100 & 19 & 21 & 218 \\
Crime section & 42 & 5 & 26 & 103 & 25 & 17 & 218 \\
Employment and social affairs & 24 & 3 & 7 & 115 & 53 & 16 & 218 \\
Science and technology & 31 & 4 & 2 & 131 & 41 & 9 & 218 \\
Economy and finance & 43 & 5 & 7 & 116 & 40 & 7 & 218 \\
Culture and art & 45 & 7 & 10 & 105 & 31 & 20 & 218 \\
National politics & 80 & 8 & 7 & 91 & 19 & 13 & 218 \\
International politics & 72 & 4 & 7 & 102 & 22 & 11 & 218 \\
\hline
\end{tabular}

Notes Column headings are as follows: (1) TV, (2) radio, (3) print media, (4) web portals, (5) search engines, (6) social networks, (7) total.

firm hypothesis 4 ( $\mathrm{H} 4)$ that 'the most frequently used media through which respondents obtain the majority of information are $\mathrm{TV}$ channels, web portals and social networks.'

\section{Conclusion}

The most important objectives of market segmentation are creating a strategy which will bring the highest possible profit with minimum costs and allow us to achieve the desired market share and competitive advantage. After a certain time, the company has to review its strategy and adapt its target segments to the new situation in the market. In addition to the correct choice and positioning in the market, the right communication with the chosen target groups is also important, i.e. by adapting individual elements of the communication mix with regard to their demographic and behavioural characteristics. Companies can use a number of various media to transfer information and influence the consumer's purchasing decisions. The best results are achieved if companies know how to correctly combine various media. In order to choose the right combination, the company has to know the characteristics of individual media and combine them so as to utilise their advantages and communicate messages to consumers with which it affects their purchasing decisions. The study focused on the consumers' lifestyle, personal values and media habits. The research results will be used as a basis 
for market segmentation and for creating effective marketing messages and choosing appropriate marketing communication tools in the analysed market.

\section{References}

Bainess, P., C. Fill, and K. Page. 2010. Marketing. New Delhi: Oxford University Press.

Damjan, J., and S. Možina. 1995. Obnašanje potrošnikov. Ljubljana: Ekonomska fakulteta.

Davies, G. J., and J. M. Brooks. 1989. Positioning Strategy in Retailing. London: Paul Chapman.

DeSarbo, W. S., V. Ramaswamy, and S. H. Cohen. 1995. 'Market Segmentation with Choice-Based Conjoint Analysis.' Marketing Letters 6 (2): 137-47.

Dibb, S., and L. Simkin. 2001. 'Market Segmentation: Diagnosing and Treating the Barriers.' Industrial Marketing Management 30 (8): 60925.

Ernst, H., W. D. Hoyer, and C. Rübsaamen. 2010. 'Sales, Marketing, and Research-and-Development Cooperation across New Product Development Stages: Implications for Success.' Journal of Marketing 74 (5): 80-92.

Fuchs, C., and A. Diamantopoulos. 2010. 'Evaluating the Effectiveness of Brand-Positioning Strategies from a Consumer Perspective.' European Journal of Marketing 44 (11-12): 1763-86.

Hassan, S. S., and S. Craft. 2012. 'Examining World Market Segmentation and Brand Positioning Strategies.' Journal of Consumer Marketing 29 (5): 344-56.

Hawkins, D. I., D. L. Mothersbaugh, and A. Mookerjee. 2010. Consumer Behaviour: Building Marketing Strategy. New Delhi: Tata McGraw Hill.

Islam, M. M. 2020. 'Segmenting, Targeting and Positioning in Islamic Marketing.' Journal of Islamic Marketing. Ahead-of-print. https:// doi.org/10.1108/JIMA-10-2018-0181

Johnson, G. 1987. Business Strategy \& Retailing. London: Wiley.

Kamakura, W. A., and G. J. Russell. 1989. 'A Probabilistic Choice Model for Market Segmentation and Elasticity Structure.' Journal of Marketing Research 26 (4): 379-90.

Kegan, W. J., and N. K. Bhargava. 2010. Global Marketing Management. New Delhi: Pearson.

Kotler, P. 1998. Marketing management - trženjsko upravljanje: analiza, načrtovanje, izvajanje in nadzor. Ljubljana: Slovenska knjiga.

Kotler, P., and G. Armstrong. 2016. Principles of Marketing. London: Pearson Education.

Kotler, P., K. L. Keller, A. Koshy, and M. Jha. 2013. Marketing Management. New Delhi: Dorling Kindersley. 
McDonald, M., and I. Dunbar. 1995. Market Segmentation: A Step-byStep Approach to Creating Profitable Market Segments. Basingstoke: Macmillan Business.

Moe, W. W., and P. S. Fader. 2001. 'Modeling Hedonic Portfolio Products: A Joint Segmentation Analysis of Music Compact Disc Sales.' Journal of Marketing Research 38 (3): 376-85.

Mumel, D. 1999. Vedenje porabnikov. Maribor: Ekonomsko-poslovna fakulteta Maribor.

Natter, M., A. Mild, U. Wagner, and A. Taudes. 2008. 'Practice Prize Report-Planning New Tariffs at Tele.ring: The Application and Impact of an Integrated Segmentation, Targeting, and Positioning Tool.' Marketing Science 27 (4): 600-9.

Peter, J. P., and J. C. Olson. 2013. Consumer Behaviour and Marketing Strategy. New Delhi: McGraw-Hill.

Porter, M. E. 1985. Competitive Advantage: Creating and Sustaining Superior Performance. New York: Free Press.

Pride, W. M., and O. C. Ferrell. 2010. Marketing: Planning, Implementation and Control. New Delhi: Cengage Learning.

Ries, A., and J. Trout. 1981. Positioning: The Battle for Your Mind. New York: McGraw-Hill.

Solomon, M., G. Bamossy, and S. Askegaard. 1999. Consumer Behaviour. London: Prentice Hall Europe.

Vukasović, T. 2018. 'Consumers' Lifestyle and Personal Characteristics as the Basis for Market Segmentation.' V Challenges of Applied Business and Social Studies, edited by P. Ašanin Gole and A. Maček, 286294. Maribor: DовA Fakulteta.

Vukasović, T. 2020. Koncepti sodobnega trženja. Harlow: Pearson Education.

Vukasović, T., and G. Jagodič. 2017. Osnove trženja in strateškega tržnega načrtovanja. Harlow: Pearson Education.

Žiberna, A. 2002. Segmentacija končnih porabnikov z uporabo statističnih metod. Ljubljana: Ekonomska fakulteta. 